\title{
Socialist Market Economic System and the Changing Trend of Labor Relations
}

\author{
Liyuan Tian \\ Baicheng Normal University, Baicheng, Jilin, 137000, China \\ email: tianliyuanwang@163.com
}

Keywords: Socialist market economic system; labor relations; trend

\begin{abstract}
With the establishment and development of China's socialist market economy, the labor employment and labor relations of many enterprises in the process of conforming to the development of the times have also undergone some changes in China. Because our country for a long time before the implemented the planned economy, so in the process of work, no matter more or less you do, the obtained benefits are as much, and then a pattern and pattern of interest integration are formed. But along with the market economy establishment and development in China, the internal power of labor relations in enterprises is gradually showing a state of imbalance, labor relations have become increasingly prominent and has become a problem that attach great importance from our government and relevant enterprises attach in the development process. In this paper, at the background of the socialist market economy system the trend of labor relations is analyzed effectively through the analysis of the reasons and the mode of its changes.
\end{abstract}

\section{Introduction}

In recent years, with the continuous development of market economy in our country with deep, our country has been completely out of the shadow and future trouble the original planned economy. At the same time, in the process of the economy change in china, two internal stakeholders identity in the enterprise labor relations are accurately defined, the internal contrasted strength of labor relations also show an unbalanced state. However, in the course of development of the whole market economy, the labor relations have become a very serious and important problem in China's enterprise. In recent years, In recent years, in the process of market economy development, our government and enterprises have been reforming the labor relations, as much as possible to make the challenges of labor relations turn into opportunities of socialist labor relations development.

\section{Reasons for the change of labor relations in the socialist market economy system}

Market Differentiation. In the course of the development of socialist market economy, the reasons for the change of China's interest pattern in the new period are the development of the market mechanism and the transformation of the social exchange pattern. In the process of transformation, In the form of possession of social resources transformation process as well as the diversification of interests and cause the legal protection of interests of different subjects in the category hierarchy different in the presence of a certain gap [1]. The different occupancy in social resources and formation of diversified interest subjects determine result in the interests the existence of a certain gap of the legal protection different subjects in the different levels of labor relations. At the same time, for different subjects, the exchange of interests needs to follow the principle of equivalence, but many subjects does not carry on the equivalent exchange according to this principle. With the development and improvement of socialist market economy, social resources have been dispersed and transferred to outside the original system in the process of development. The state's possession and control of social resources are constantly decreasing, so that it can be controlled and utilized by enterprises and individuals. At the same time, the distribution of the social resources not controlled by the state need go through the relevant negotiations, exchange and competition and so on a series of way to access to gain, and that can effectively improve the market economic development, promote the transformation and development of labor relations in market economy. 
Establishment of Enterprise Market Subjectivity. In the course of China's transition from planned economy to market economy, the interests of the relevant government, enterprises and even individuals have received more or less affected. In particular, the labor relations in China's state-owned enterprises have shown a direction of interest differentiation and coordination, and the internal contrasted power of labor relations show an unbalanced state. In addition, the regulation and transformation of labor relations in enterprises has been transferred from the original state control to the regulation and transformation of enterprise itself, the management and control range and intensity of the state to enterprise are constantly decreasing, the right of the development is be returned to the enterprise itself, thus that effectively improve the development efforts of the enterprise in the market economy and raise economic benefits of the enterprises in society [2].

But from the current situation of the development of labor relations in most enterprises in China, although the enterprise has realized the independent operation and development, in the actual process of production and development, enterprise employees rely on enterprises stronger [3]. At the same time, the vast majority of enterprises take the administrative means to carry out control and regulation in the labor relations, through the signing of labor contracts for control and management of employees, of which there are some defects and the phenomenon is not perfect. In addition, there are many enterprises, especially labor-intensive enterprises, have a situation of surplus labor force, the labor relations, contrasted power and power structure, planning exist imbalance, laborer is in a weak position.

Establishment of Enterprise Employee Dominant Position. In the process of developing socialist market economy, our country not only established public ownership economy system, also formed a set of bilateral labor relations between government and workers, so as to fully break the traditional concept of "a secure job" and thought. With the development and deepening of market economy in China, the labor force has gradually formed a market in recent years, the phenomenon of labor commercialization gradually is obvious, and the competition is also increasing. Therefore, in the process of development of market economy, enterprises obtain the power of free operation, at the same time workers also fully have the individual ownership of labor force commodity, people are free and equal to choose works, that comprehensively improve individual and comprehensive development of the labor.

\section{Current Situation of Change of Labor Relations Transformation in Socialist Market Economy System}

Diversified Types of Labor Relations. With the development and deepening of market economy and various economic forms in our country, the labor relations in enterprises also present a diversified trend. Today, in addition to the state-owned economy and the collective economy, in the process of development of labor relations, the shareholding system, cooperation system, as well as individual and even a series of foreign labor relations have also been increased. At the same time, in today's market economy development process, many enterprises in a ownership economy type, but also contains a number of different forms of labor relations. For example, state-owned economic enterprises in the internal will also include contracting, leasing, stockholding system and other forms, that makes the labor relations be different and in a variety of types [4]. Therefore, with the continuous development and improvement of market economy in our country, labor relations in the enterprise also produce a huge change with the change of the market economy, and show a variety of types, and then that promote enterprises to get better economic efficiency in business in the process of running and development.

Explicitation of Subject of Labor Relations. In the development of market economy, labor relation in enterprises is a kind of interest relation. Under normal circumstances, this interest relationship is coordinated through the contract, through the signing of labor contracts for effective control. At the same time, along with the continuous development and improvement of the market economy in our country, the government, enterprises and workers' status in the labor relations gradually clear, and are increased and improved continuously during the development of the market economy, that has achieve a mutually beneficial labor relations. As the subject of labor relations 
continue to be clear, the different subjects share a certain of definite interests in the development process of production, which can increase the working enthusiasm of the related subjects and enhance their economic benefits.

Along with the development and the deepening of market economy in China, enterprises in the process of establishing labor relations, need more communication and consultation with related staff, which can effectively avoid the occurrence of labor disputes and encourage enterprises to maintain normal production and development [5]. Through the establishment of communication and consultation system within the enterprise, the legitimate rights and interests of working people in the enterprise can be protected well, thus that can promote the good development and construction of enterprises. In addition, in the process of economic development, negotiation is an important guarantee to promote the smooth transition and market economy development, It not only to protect the interests of employees within the enterprise and enhance the enterprise's economic growth and development that promoting the enterprise internal employee relations form a contract form.

Marketization of Labor Relations. With the continuous development and improvement of China's market economy, the role of the market during the process of development in labor relations is strengthening and improving constantly, which causes enterprises to continuously reduce labor costs and enhance the core competitiveness. In recent years, with the improvement of the market economy in China, the labor market has also been improved to a certain extent; China's market-oriented economic development system has gradually become a market-oriented economy which takes use of a labor contract as the carrier, the market price for the direction of development. These market-oriented labor relations can promote labor relations to be gradually enhanced in the development and the process of operation, and promote the entire labor relations more harmonious and have less labor conflicts

Evidence of Labor Conflict. In view of the current situation of labor relations in the process of China's current market economy development, China's market economy still has some deficiencies in the market mechanism and the relevant legal system [6]. The relevant legal system of market economy does not conform to the development of the times and make some updates, the legal system is lagging behind, the lack of legal basis for many, that causing the market economy to have many problems in the process of the development and operation. In addition, because of the employment pressure of the workers greater, the phenomenon and behavior of enterprise violation of related rights and interests of employees are not exposed, which caused a lot of conflicts and contradictions. In recent years, with the reform and development of the market economy system, the maintenance consciousness of laborers to their own rights is continuously strengthened, which highlights deep-seated contradictions in the traditional system of labor relations, the contradictions in the process of reform and development and the phenomenon of violating the rights and interests of laborers, and make conflict of labor be apparent.

\section{The Change Trend of Labor Relations in Socialist Market Economy}

Perfect the Labor Market. In the development process of market economy, the establishment and improvement of labor market gradually formed labor relations. But during the development of the market economy, the labor market is one of the important production factor market, that is effectively implemented through the rational allocation of labor resources in the market economy system and can effectively improve the workers' scientific literacy, scientific knowledge and professional skills, and promote the development and improvement of workers overall. In addition, the labor market can also effectively stimulate the competitiveness and enthusiasm of labor in the market competition, and improve the production efficiency, so as to make the enterprise's production efficiency can be effectively improved, thereby promoting the economic benefits of the enterprise be comprehensive development. However, on China's current market development status, the labor markets in China are still not perfect and have many defects. Although China in many areas and cities has set up a large talent market, but in the actual application process, but the mechanism of market exchange of free competition of the labor supply and demand sides, is not realized, that results in enterprises be shortage of labor resources of and be difficult to obtain 
through market effective labor. At the same time, a large number of labor is difficult to free access to the market, unable to seek suitable labor opportunities, and thus bring the entire labor market resource allocation a great impact. In this regard, the employers need to do some plan and reform in the employment system and use and formulate personnel management system scientifically and reasonably, and then promote the different levels of the working people to have the corresponding market of supply and demand. In addition, it is necessary to timely improve and update the professional information service consulting system and timely update the relevant consulting information, prompting both sides of labor supply and demand to communicate and communicate information.

Perfecting of Labor Law. With the continuous improvement and deepening of China's market economy, the corresponding labor law needs to be improved with the development of the times. The trade union law promulgated in 2001 in China is an important breakthrough of labor legislation. With the continuous growth of the number of joint-stock and small and medium enterprises, the system reform of state-owned enterprise has undergone a series of changes. The problems in the actual management process, need to be strengthened the control of relevant laws, and the relevant "labor contract law", "collective contract law" and a series of laws need be updated and improved conforming the development trend of the times, which can guarantee the efficient workers and working people, and safeguard the legitimate rights and interests of labors in the dispute of the labor relation.

Reform of Trade Unions. Trade unions are the interests representatives of workers in the enterprise, through the formation of relevant collective contracts to regulate the rights and obligations of both sides, effective maintain labor relations. However, in the process of the reform of the labor system, the manage and control of whole enterprise is implemented by implementing the collective contract system in the enterprise. In this regard, trade unions in the development process also need to adapt to the corresponding reform, and then take the relevant measures to reform and update, so as to protect the legitimate rights and interests of workers. Strengthening the link between the party and workers, trade unions can prompt enterprises to receive a certain degree of management by the state in the development process. Therefore, countries need to strengthen the management to the actual control of the union management authority, protect the rights and interests of workers trade unions, and prompt union workers from the actual situation of aspects to enhancing the interests of the workers effectively.

\section{Summary}

In the course of development of market economy, both the implementation of positive labor relations and economic reform are complementary to each other, which can promote China's better construction and development. In this regard, in the process of the development of the market economy the government and enterprises need adjust the market and labor relations combined with the background characteristics of the times, which can guarantee the interests of employees and workers effectively, improve the market economic development present situation, and promote the enterprise be in healthy and continuous development in the process of development of market economy.

\section{Reference}

[1] WANG Yang. Research on the development trend of labor relations in China[J].Labor Economic Review, 2012(6).

[2] NIU Youning. Thoughts on creating harmonious labor relations institutional environment[J]. Study on the labor movement, 2011(3).

[3] SHEN Qinqin. FU Lin. Transformation and development of labor relations in China[J].Modern Communication, 2009(4). 
[4] ZHANG Liqiang. Doing well trade union coordination work and constructing harmonious labor relations[J], Management scientist,2013(2).

[5] Wang Jinhuan. Before and after the reform of our country labor relations comparative study [J]. Modern commercial and trade industry, 2013 (2).

[6] Chen Biaobiao, Liu Sheng. Building a harmonious socialist new labor relations empirical study [J]. Journal of horizon of science and technology, 2016 (5). 